\title{
Documentation of Pyrethroid Resistance against Brinjal Shoot and Fruit Borer, Leucinodes orbonalis Guenee (Pyralidae: Lepidoptera)
}

\author{
S. Murali ${ }^{*}$, S.K. Jalali ${ }^{2}$, A.N. Shylesha ${ }^{2}$, T.M. Shivalinga Swamy ${ }^{2}$ and R. Gandhi Gracy ${ }^{2}$ \\ ${ }^{1} \mathrm{CSB}$, RSRS, Jammu - 181101, J \& K, India \\ ${ }^{2}$ NBAIR, Bengaluru - 560024, Karnataka, India \\ *Corresponding author
}

\section{A B S T R A C T}

In the present investigation, differential response was observed in different populations of $L$. orbonalis with respect to six different pyrethroids, viz.,

Keywords

L. orbonalis,

Pyrethroids,

Resistant,

Susceptible, $\mathrm{LC}_{50}$

Article Info

Accepted:

26 June 2017

Available Online:

10 August 2017 alphamethrin, cypermethrin, deltamethrin, fenvalerate, $\lambda$-cyhalothrin, and fenpropathrin. The Kolar population was found to be most susceptible to alphamethrin, deltamethrin and $\lambda$-cyhalothrin with $\mathrm{LC}_{50}$ values of $0.01,0.02$ and $0.02 \mathrm{ml} / \mathrm{l}$, respectively, while Belagavi and Bengaluru and Koppal population were recorded most susceptible to cypermethrin, fenvalerate and fenpropathrin, $\mathrm{LC}_{50}$ values ranged from 0.04 to $0.13 \mathrm{ml} / \mathrm{l}$. The results also suggested different pyrethroids use pattern in different places, among different populations, Koppal population was found 24-fold resistant to alphamethrin, Belagavi population was 12 -fold resistant to deltamethrin, Bengaluru population was 10.5 -fold resistant to $\lambda$-cyhalothrin and Belagavi population was 2.5 -fold more resistant to fenpropathrin. However, all populations were found to be highly susceptible to cypermethrin and highly resistant to fenvalerate as $\mathrm{LC}_{50}$ values ranged from 0.13 to $0.26 \mathrm{ml} / \mathrm{l}$ for different populations.

\section{Introduction}

Study of insecticide resistance is one of the key components to devise control measures, by altering the use of different groups of insecticides. There are several studies that suggest most of the insecticides do not provide satisfactory control of brinjal shoot and fruit borer (BSFB), thereby resulting in crop losses, leading to indiscriminate use in many parts of the country and elsewhere. Such scenario often results in development of resistance, which leads to misuse of insecticides and threaten environmental safety and cause health hazards. Although the resistance is a natural mechanism for survival, its development has been accelerated in recent year due to excessive dependence upon chemical pesticides. Insecticides resistance in BSFB especially to pyrethroids is now widespread in many brinjal-producing countries. Due to resistance, pest management program is likely to suffer and to some extent would be ineffective resulting serious reduction of crop production. It is therefore, necessary to undertake further studies towards recognition and monitoring of resistance in BSFB and other insects that are exposed very frequently to high selection pressure of insecticides. 
The genetic plasticity of $L$. orbonalis is apparent in its ability to detoxify many synthetic insecticides in addition to the secondary plant metabolites present in its narrow array of host plant species. In response to the stresses, the populations of $L$. orbonalis have adapted to the insecticide applications by changing their ecobehavioural pattern, feeding physiology and reproduction (Isahaque and Chaudhuri, 1984). This in turn led to excessive and indiscriminate use of insecticides (spraying upwards of 40 times per season) by desperate farmers (Shelton, 2010). Pesticide resistance is emerging as one of the key constraints to successful crop protection and public health problems worldwide (Dover and Croft, 1984). Insecticides resistance in $L$. orbonalis especially to pyrethroids is now widespread in many brinjal-producing countries, which is evident from reports of great variations in the requirements of pesticides application in different areas. Resistance detection is the vital components of pesticide resistance management. It aims to identify the initial presence of resistant individuals in a pest population.

\section{Materials and Methods}

\section{Field population}

Leucinodes orbonalis larvae collected from 5 different places of Karnataka and reared under laboratory condition on naturally available potato to obtain healthy culture, and $\mathrm{F}_{2}$ generation larvae were used for measuring insecticide resistance. The bioassay methods should closely simulate field-conditions to ensure predictability of control efficacy in the field from data obtained through labmeasured resistance. Over the past two decades, bioassay methods based on leaf-dip, larval dip, topical application, leaf spraying and vial-residue were developed as viable alternatives to simulated field conditions
(Kranthi, 2005). The leaf/foliar spray method was used under laboratory condition for concentration - mortality test of BSFB. Each insecticide tested was diluted to get six concentrations for each of the selected insecticides.

\section{Procedure of testing resistance}

Five BSFB populations from Bengaluru, Doddaballapur, Kolar, Koppal and Belagavi were used for detection of insecticide resistance. The experiment was conducted at NBAIR, Bengaluru, from May to September, 2014. The neonates were used for testing of resistance and the observations were taken at $24 \mathrm{~h}$. Before standardizing this time, mortality was observed for different time intervals from $1 \mathrm{~h}$ to up to $48 \mathrm{~h}$. At $48 \mathrm{~h}$, all the larvae were dead in all the different concentrations, which were used for detecting resistance and even in control more than 90 per cent mortality was recorded, therefore, the observation was restricted at $24 \mathrm{~h}$ only. For conducting bioassay, neonates were used because, after hatching, larvae bore into the tender midribs of leaves or shoots or twigs or fruits and feeds inside up to final instar and come out only for pupation on calyx of fruits or on leaves or debris at base of the plant.

\section{Insecticide treatments}

The brinjal leaves were always collected from plants raised in earthen pots and such plants were not sprayed throughout experiment. The stalk of the leaves were firmly covered with finely teased wet cotton to maintain tenderness of the leaves and then the leaves were sprayed in discriminating concentration ( $2 \mathrm{ml}, 0.5 \mathrm{ml}, 0.125 \mathrm{ml}, 0.0312 \mathrm{ml}, 0.008 \mathrm{ml}$ and $0.002 \mathrm{ml}(4$ insecticides, viz., cypermethrin $25 \%$ EC, deltamethrin $2.8 \%$ EC, alphamethrin $10 \%$ EC fenpropathrin 20 $\%$ EC) and $4 \mathrm{ml}, 1 \mathrm{ml}, 0.25 \mathrm{ml}, 0.062 \mathrm{ml}$, $0.016 \mathrm{ml}, 0.004 \mathrm{ml}$ (2 insecticides, viz., 
lambda cyhalothrin $5 \%$ EC, fenvalerate $20 \%$ EC) of the each insecticides and air dried. Thus, the leaves of the brinjal were made ready for use. The leaves were sprayed with the water only to serve as control. Ten larvae were released in each concentration thus, 70 larvae were used for one replication and each experiment was replicated 5 times. There were six different dilutions of each chemical for bioassay with five replications. Initial screening were done with only ten number of neonate larvae from field collected population, using six broad range of dilutions to decide on the dilution range to be used and it is called bracketing. So, initial bracketing was done and the final dilution of each insecticide was done. The different concentrations of field recommended insecticides were prepared by using water and water is used as control.

\section{Statistical method for $\mathrm{LC}_{50}$ calculation}

Log dose probit analysis was carried out to obtain $\mathrm{LC}_{50}$ and $\mathrm{LC}_{90}$ values, fiducial limits and regression equation that enable the calculation of the dose / concentration required for any particular per cent mortality that they cause in the test population developed on the basis of Finney's (1971) method. Once the bioassay results were found to confirm to a graded response depending on the concentration of the toxicant, they were then subjected to probit analysis through a series of manual calculations or on computeraided programs, for this study, the data were analyzed using SPSS 16 Version of Statistical Programme.

\section{Results and Discussion}

\section{Alphamethrin}

The susceptibility of $L$. orbonalis populations for alphamethrin varied greatly (Table 1). Among the five populations, Kolar populations were more susceptible to the insecticide $\left(\mathrm{LC}_{50}: 0.01 \mathrm{ml} / \mathrm{l}\right)$, followed by Bengaluru (0.04 ml/l), Doddaballapur (0.05 $\mathrm{ml} / \mathrm{l})$, Belagavi $(0.12 \mathrm{ml} / \mathrm{l})$ and Koppal (0.24 $\mathrm{ml} / \mathrm{l})$. The Koppal populations were more resistant when compared to the other field populations. The non-overlapping method of statistical analysis showed that the Kolar populations were highly distinct, it was separated from other populations having fiducial limit ranging from 0.01-0.02, followed by Bengaluru and Doddaballapur populations, which overlapped with each other having fiducial limits that ranged from 0.03-0.07, while population from Belagavi and Koppal formed a distinct cluster because they overlapped with each other but were distinct from other populations (Table 1; Fig. 1).

\section{Cypermethrin}

The median lethal dose concentrations of cypermethrin for five field populations of $L$. orbonalis ranged from 0.04 to $0.07 \mathrm{ml} / 1$ (Table 2). Belagavi populations were more susceptible $\left(\mathrm{LC}_{50}: 0.04 \mathrm{ml} / \mathrm{l}\right)$, followed by Koppal (0.05 ml/l), Doddaballapur (0.05 ml/l) and Bengaluru $(0.06 \mathrm{ml} / \mathrm{l})$. The Kolar population $(0.07 \mathrm{ml} / \mathrm{l})$ was found to be relatively more tolerant to the insecticide. However, there was no statistical difference between the populations estimated by nonoverlap of fiducial limit (Fig. 2).

\section{Deltamethrin}

The median lethal dose concentrations of cypermethrin for five field populations of $L$. orbonalis ranged from 0.02 to $0.24 \mathrm{ml} / \mathrm{l}$ (Table 3). Kolar populations were most susceptible to the insecticide $\left(\mathrm{LC}_{50}: 0.02 \mathrm{ml}\right)$, followed by Bengaluru (0.03 ml/l), Koppal (0.04 ml/l), Doddaballapur $(0.15 \mathrm{ml} / \mathrm{l})$ and Belagavi $(0.24 \mathrm{ml} / \mathrm{l})$. The Belagavi populations were more resistant to this 
insecticide (Table 3). The non-overlapping method of statistical analysis revealed that the populations from Bengaluru, Kolar and Koppal were statistically on par with each other, however, Doddaballapur and Belagavi populations were distinct, therefore, highly resistant (Fig. 3).

\section{Fenvalerate}

The bioassays revealed that Bengaluru and Koppal field populations were relatively susceptible to insecticide $\left(\mathrm{LC}_{50}: 0.13 \mathrm{ml} / \mathrm{l}\right)$, followed by Belagavi $(0.16 \mathrm{ml} / \mathrm{l})$, Doddaballapur $(0.24 \mathrm{ml} / \mathrm{l})$ and Kolar $(0.26$ $\mathrm{ml} / \mathrm{l})$. The Kolar population was recorded as most tolerant to this insecticide (Table 4). Comparison of statistical analysis based on non-overlap method indicated that all populations were on par with each other in terms of their tolerance to this insecticide (Fig. 4).

\section{Lambda cyhalothrin}

The susceptibility of $L$. orbonalis populations to lambda cyhalothrin varied greatly (Table 5). Among the five populations, Kolar populations were most susceptible to the insecticide $\left(\mathrm{LC}_{50}: 0.02 \mathrm{ml} / \mathrm{l}\right)$, followed by Doddaballapur $(0.10 \mathrm{ml} / \mathrm{l})$, Belagavi (0.12 $\mathrm{ml} / \mathrm{l}$ ) and Bengaluru, Koppal populations were resistant to the insecticide $(0.21 \mathrm{ml} / \mathrm{l})$ (Table 5). The non-overlapping method of statistical analysis revealed that Kolar population was a distinct one and all other populations were on par with each other (Fig. 5).

\section{Fenpropathrin}

The median lethal dose concentrations of fenpropathrin to five field populations of $L$. orbonalis ranged from 0.08 to $0.20 \mathrm{ml}$ (Table $6)$. The results indicated that Bengaluru and Koppal populations were most susceptible to the insecticide $\left(\mathrm{LC}_{50}: 0.08 \mathrm{ml} / \mathrm{l}\right)$, followed by Kolar $(0.14 \mathrm{ml} / \mathrm{l})$, Doddaballapur $(0.19 \mathrm{ml} / \mathrm{l})$ and Belagavi populations which were more resistant to insecticide $(0.20 \mathrm{ml} / \mathrm{l})$. Among all the populations collected from the five locations, Bengaluru and Koppal populations had similar susceptibility as indicated by nonoverlap method of population, whereas Bengaluru and Kolar populations were similar as their fiducial limits overlapped and Doddaballapur, Kolar and Belagavi were not significantly different from each other (Table 6; Fig. 6).

In the present investigation, differential response was observed in different populations of $L$. orbonalis with respect to six different pyrethroids, viz., alphamethrin, cypermethrin, deltamethrin, fenvalerate, $\lambda$ cyhalothrin, and fenpropathrin. Kolar population was found to be most susceptible to alphamethrin, deltamethrin and $\lambda$ cyhalothrin with $\mathrm{LC}_{50}$ values of $0.01,0.02$ and $0.02 \mathrm{ml} / \mathrm{l}$, respectively, while Belagavi and Bengaluru \& Koppal population were recorded most susceptible to cypermethrin, fenvalerate \& fenpropathrin, $\mathrm{LC}_{50}$ values ranged from 0.04 to $0.13 \mathrm{ml} / 1$. The results also suggested different pyrethroids use pattern in different places. Among different populations, Koppal population was found 24-fold resistant to alphamethrin, Belagavi population was 12-fold resistant to deltamethrin, Bengaluru population was 10.5 -fold resistant to $\lambda$-cyhalothrin and Belagavi population was 2.5-fold more resistant to fenpropathrin. However, all populations were found to be highly susceptible to cypermethrin and highly resistant to fenvalerate as $\mathrm{LC}_{50}$ values ranged from 0.13 to $0.26 \mathrm{ml} / \mathrm{l}$ for different populations. In a earlier study, a high degree of resistance to pyrethroids (cypermethrin, fenvalerate and deltamethrin) and an organophosphate (quinalphos) was recorded for L. orbonalis from different parts of India (Saxena et al., 1989). 
Table.1 The probit analysis of dosage mortality response of field populations of L. orbonalis to alphamethrin

\begin{tabular}{|c|c|c|c|c|c|c|c|c|c|c|}
\hline \multirow{2}{*}{ Population } & \multirow{2}{*}{$\begin{array}{r}\mathrm{LC}_{50} \\
(\mathrm{ml} / \mathrm{l})\end{array}$} & \multicolumn{2}{|c|}{ Fiducial limit } & \multirow{2}{*}{$\begin{array}{r}\mathbf{L C}_{90} \\
(\mathbf{m l} / \mathbf{l})\end{array}$} & \multicolumn{2}{|c|}{ Fiducial limit } & \multirow{2}{*}{$\begin{array}{c}\begin{array}{c}\text { Regression } \\
\text { equation }\end{array} \\
\mathbf{Y}=\mathbf{a}+\mathbf{b x}\end{array}$} & \multirow{2}{*}{$\begin{array}{c}\text { Chi-square } \\
\text { value }\end{array}$} & \multirow{2}{*}{ df } & \multirow{2}{*}{ Probability } \\
\hline & & Lower & Upper & & Lower & Upper & & & & \\
\hline Bengaluru & 0.04 & 0.031 & 0.07 & 1.19 & 0.63 & 2.92 & $1.21+0.91 \mathrm{x}$ & 29.64 & 28 & 0.38 \\
\hline Doddaballapur & 0.05 & 0.03 & 0.07 & 0.79 & 0.46 & 1.63 & $1.39+1.09 \mathrm{x}$ & 14.97 & 28 & 0.97 \\
\hline Kolar & 0.01 & 0.01 & 0.02 & 0.74 & 0.36 & 2.07 & $1.38+0.78 \mathrm{x}$ & 19.32 & 28 & 0.88 \\
\hline Belagavi & 0.12 & 0.08 & 0.18 & 2.65 & 1.34 & 6.93 & $0.87+0.95 x$ & 28.23 & 28 & 0.45 \\
\hline Koppal & 0.24 & 0.15 & 0.41 & 6.85 & 3.01 & 22.72 & $0.54+0.88 \mathrm{x}$ & 32.27 & 28 & 0.26 \\
\hline
\end{tabular}

Table.2 The probit analysis of dosage mortality response of field populations of L. orbonalis to cypermethrin

\begin{tabular}{|c|c|c|c|c|c|c|c|c|c|c|}
\hline \multirow{2}{*}{ Population } & \multirow{2}{*}{$\begin{array}{l}\mathbf{L C}_{50} \\
(\mathbf{m l} / \mathbf{l})\end{array}$} & \multicolumn{2}{|c|}{ Fiducial limit } & \multirow{2}{*}{$\begin{array}{r}\mathbf{L C}_{90} \\
(\mathbf{m l} / \mathbf{l})\end{array}$} & \multicolumn{2}{|c|}{ Fiducial limit } & \multirow{2}{*}{$\begin{array}{c}\begin{array}{c}\text { Regression } \\
\text { equation }\end{array} \\
\mathbf{Y}=\mathbf{a}+\mathbf{b x}\end{array}$} & \multirow{2}{*}{$\begin{array}{c}\text { Chi-square } \\
\text { value }\end{array}$} & \multirow{2}{*}{ df } & \multirow{2}{*}{ Probability } \\
\hline & & Lower & Upper & & Lower & Upper & & & & \\
\hline Bengaluru & 0.06 & 0.045 & 0.08 & 0.57 & 0.36 & 1.05 & $1.60+1.33 x$ & 21.71 & 28 & 0.79 \\
\hline Doddaballapur & 0.05 & 0.03 & 0.08 & 3.62 & 1.44 & 14.70 & $0.89+0.69 \mathrm{x}$ & 14.96 & 28 & 0.97 \\
\hline Kolar & 0.07 & 0.04 & 0.10 & 1.02 & 0.59 & 2.13 & $1.27+1.10 \mathrm{x}$ & 23.39 & 28 & 0.71 \\
\hline Belagavi & 0.04 & 0.03 & 0.06 & 0.61 & 0.36 & 1.23 & $1.51+1.11 \mathrm{x}$ & 26.00 & 28 & 0.57 \\
\hline Koppal & 0.05 & 0.03 & 0.08 & 1.53 & 0.78 & 3.99 & $1.11+0.88 \mathrm{x}$ & 23.14 & 28 & 0.72 \\
\hline
\end{tabular}

Table.3 The probit analysis of dosage mortality response of field populations of L. orbonalis to deltamethrin

\begin{tabular}{|c|c|c|c|c|c|c|c|c|c|c|}
\hline \multirow{2}{*}{ Population } & \multirow{2}{*}{$\begin{array}{l}\mathbf{L C}_{50} \\
(\mathrm{ml} / \mathrm{l})\end{array}$} & \multicolumn{2}{|c|}{ Fiducial limit } & \multirow{2}{*}{$\begin{array}{r}\mathbf{L C}_{90} \\
(\mathbf{m l} / \mathbf{l})\end{array}$} & \multicolumn{2}{|c|}{ Fiducial limit } & \multirow{2}{*}{$\begin{array}{c}\begin{array}{c}\text { Regression } \\
\text { equation }\end{array} \\
\mathbf{Y}=\mathbf{a}+\mathbf{b x} \\
\end{array}$} & \multirow{2}{*}{$\begin{array}{c}\text { Chi-square } \\
\text { value }\end{array}$} & \multirow{2}{*}{ df } & \multirow{2}{*}{ Probability } \\
\hline & & Lower & Upper & & Lower & Upper & & & & \\
\hline Bengaluru & 0.03 & 0.021 & 0.04 & 0.81 & 0.43 & 1.92 & $1.36+0.91 \mathrm{x}$ & 17.58 & 28 & 0.93 \\
\hline Doddaballapur & 0.15 & 0.13 & 0.30 & 2.18 & 1.22 & 4.90 & $0.90+1.11 x$ & 21.12 & 28 & 0.82 \\
\hline Kolar & 0.02 & 0.01 & 0.03 & 0.53 & 0.28 & 1.25 & $1.53+0.90 \mathrm{x}$ & 17.87 & 28 & 0.92 \\
\hline Belagavi & 0.24 & 0.15 & 0.41 & 6.85 & 3.01 & 22.72 & $0.54+0.88 \mathrm{x}$ & 32.27 & 28 & 0.26 \\
\hline Koppal & 0.04 & 0.03 & 0.07 & 1.53 & 0.75 & 4.16 & $1.12+0.85 \mathrm{x}$ & 27.13 & 28 & 0.51 \\
\hline
\end{tabular}


Table.4 The probit analysis of dosage mortality response of field populations of L. orbonalis to fenvalerate

\begin{tabular}{|c|c|c|c|c|c|c|c|c|c|c|}
\hline \multirow{2}{*}{ Population } & \multirow{2}{*}{$\begin{array}{l}\mathbf{L C}_{50} \\
(\mathbf{m l} / \mathbf{l})\end{array}$} & \multicolumn{2}{|c|}{ Fiducial limit } & \multirow{2}{*}{$\begin{array}{r}\mathbf{L C}_{90} \\
(\mathbf{m l} / \mathbf{l})\end{array}$} & \multicolumn{2}{|c|}{ Fiducial limit } & \multirow{2}{*}{$\begin{array}{c}\text { Regression equation } \\
\mathbf{Y}=\mathbf{a}+\mathbf{b x}\end{array}$} & \multirow{2}{*}{$\begin{array}{l}\text { Chi-square } \\
\text { value }\end{array}$} & \multirow{2}{*}{ df } & \multirow{2}{*}{ Probability } \\
\hline & & Lower & Upper & & Lower & Upper & & & & \\
\hline Bengaluru & 0.13 & 0.076 & 0.24 & 13.95 & 5.13 & 66.86 & $0.55+0.63 x$ & 32.98 & 28 & 0.23 \\
\hline Doddaballapur & 0.24 & 0.16 & 0.37 & 5.40 & 2.73 & 14.21 & $0.58+0.94 x$ & 14.28 & 28 & 0.98 \\
\hline Kolar & 0.26 & 0.17 & 0.39 & 5.32 & 2.73 & 13.55 & $0.57+0.97 x$ & 19.23 & 28 & 0.89 \\
\hline Belagavi & 0.16 & 0.11 & 0.24 & 2.72 & 1.53 & 6.05 & $0.82+1.05 \mathrm{x}$ & 19.24 & 28 & 0.89 \\
\hline Koppal & 0.13 & 0.09 & 0.19 & 1.93 & 1.12 & 4.05 & $0.96+1.10 x$ & 15.62 & 28 & 0.97 \\
\hline
\end{tabular}

Table.5 The probit analysis of dosage mortality responses of field populations of $L$. orbonalis to lambda cyhalothrin

\begin{tabular}{|c|c|c|c|c|c|c|c|c|c|c|}
\hline \multirow{2}{*}{ Population } & \multirow{2}{*}{$\begin{array}{l}\mathbf{L C}_{50} \\
(\mathrm{ml} / \mathrm{l})\end{array}$} & \multicolumn{2}{|c|}{ Fiducial limit } & \multirow{2}{*}{$\begin{array}{l}\mathrm{LC}_{90} \\
(\mathrm{ml} / \mathrm{l})\end{array}$} & \multicolumn{2}{|c|}{ Fiducial limit } & \multirow{2}{*}{$\begin{array}{c}\text { Regression equation } \\
\mathbf{Y}=\mathbf{a}+\mathbf{b x}\end{array}$} & \multirow{2}{*}{$\begin{array}{c}\text { Chi-square } \\
\text { value }\end{array}$} & \multirow{2}{*}{ df } & \multirow[b]{2}{*}{ Probability } \\
\hline & & Lower & Upper & & Lower & Upper & & & & \\
\hline Bengaluru & 0.21 & 0.146 & 0.31 & 3.82 & 2.16 & 8.37 & $0.68+1.02 x$ & 30.25 & 28 & 0.35 \\
\hline Doddaballapur & 0.10 & 0.07 & 0.14 & 1.48 & 0.87 & 3.04 & $1.09+1.10 \mathrm{x}$ & 14.50 & 28 & 0.98 \\
\hline Kolar & 0.02 & 0.01 & 0.04 & 0.88 & 0.47 & 2.17 & $1.32+0.84 \mathrm{x}$ & 26.44 & 28 & 0.54 \\
\hline Belagavi & 0.12 & 0.08 & 0.19 & 3.71 & 1.84 & 10.10 & $0.78+0.86 x$ & 19.06 & 28 & 0.89 \\
\hline Koppal & 0.21 & 0.13 & 0.334 & 8.09 & 3.77 & 24.64 & $0.54+0.80 \mathrm{x}$ & 33.97 & 28 & 0.20 \\
\hline
\end{tabular}

Table.6 The probit analysis of dosage mortality response of field populations of L. orbonalis to fenpropathrin

\begin{tabular}{|c|c|c|c|c|c|c|c|c|c|c|}
\hline \multirow{2}{*}{ Population } & \multirow{2}{*}{$\begin{array}{l}\mathbf{L C}_{50} \\
(\mathrm{ml} / \mathrm{l})\end{array}$} & \multicolumn{2}{|c|}{ Fiducial limit } & \multirow{2}{*}{$\begin{array}{r}\mathbf{L C}_{90} \\
(\mathbf{m l} / \mathbf{l})\end{array}$} & \multicolumn{2}{|c|}{ Fiducial limit } & \multirow{2}{*}{$\begin{array}{c}\begin{array}{c}\text { Regression } \\
\text { equation }\end{array} \\
\mathbf{Y}=\mathbf{a}+\mathbf{b x}\end{array}$} & \multirow{2}{*}{$\begin{array}{c}\text { Chi-square } \\
\text { value }\end{array}$} & \multirow{2}{*}{ df } & \multirow{2}{*}{ Probability } \\
\hline & & Lower & Upper & & Lower & Upper & & & & \\
\hline Bengaluru & 0.08 & 0.04 & 0.14 & 7.38 & 2.78 & 34.40 & $0.95+0.77 x$ & 25.28 & 28 & 0.58 \\
\hline Doddaballapur & 0.19 & 0.14 & 0.33 & 3.79 & 1.97 & 9.55 & $0.74+1.02 x$ & 17.70 & 28 & 0.90 \\
\hline Kolar & 0.14 & 0.09 & 0.21 & 2.92 & 1.50 & 7.40 & $1.05+0.93 \mathrm{x}$ & 18.55 & 28 & 0.90 \\
\hline Belagavi & 0.20 & 0.13 & 0.32 & 4.78 & 2.27 & 14.38 & $0.68+0.96 \mathrm{x}$ & 25.75 & 28 & 0.57 \\
\hline Koppal & 0.08 & 0.06 & 0.13 & 1.73 & 0.93 & 4.10 & $1.04+0.97 \mathrm{x}$ & 21.37 & 28 & 0.74 \\
\hline
\end{tabular}


Fig.1 The probit analysis of dosage mortality response of field populations of L. orbonalis to alphamethrin

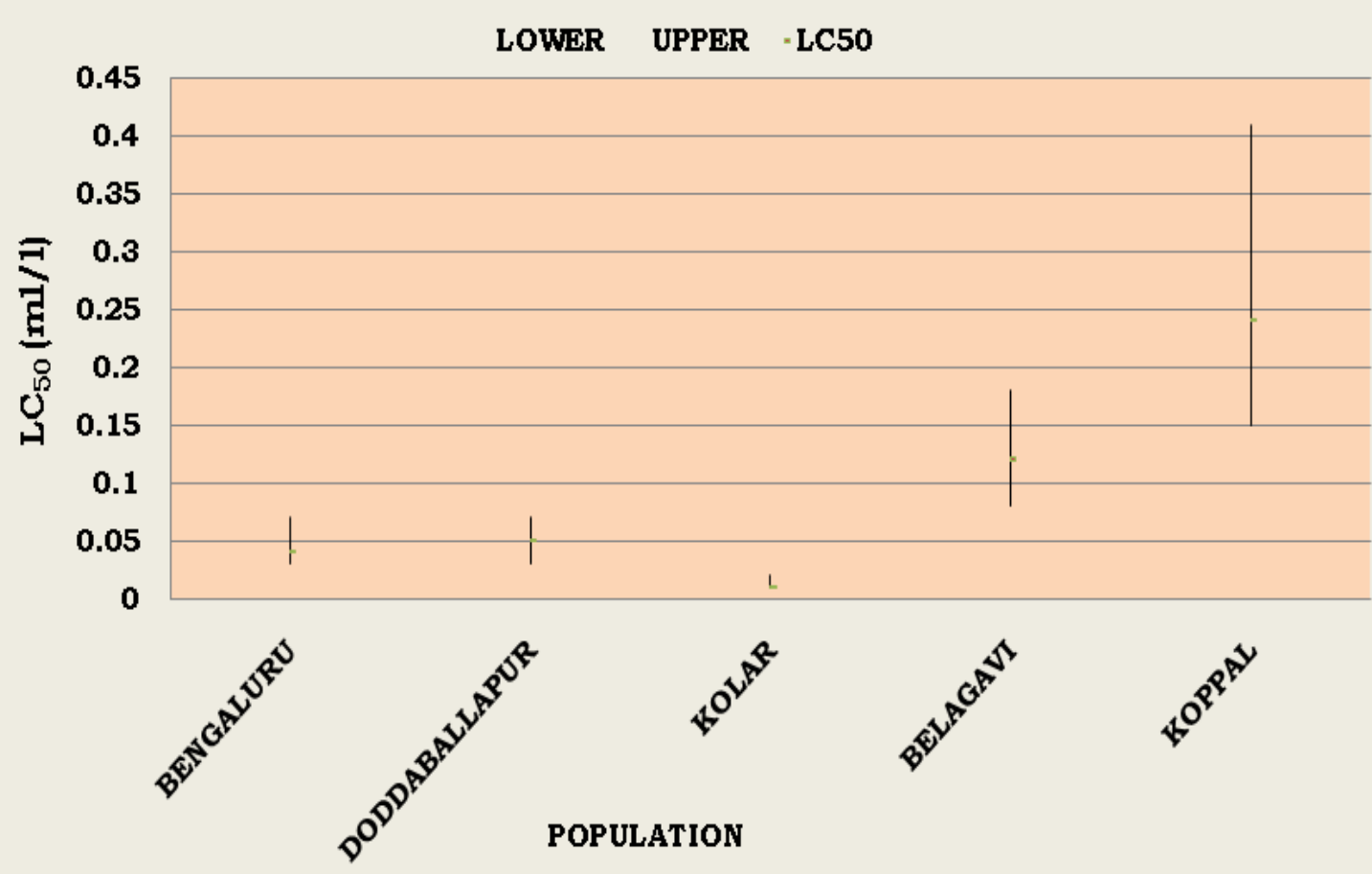

Fig.2 The probit analysis of dosage mortality response of field populations of L. orbonalis to cypermethrin

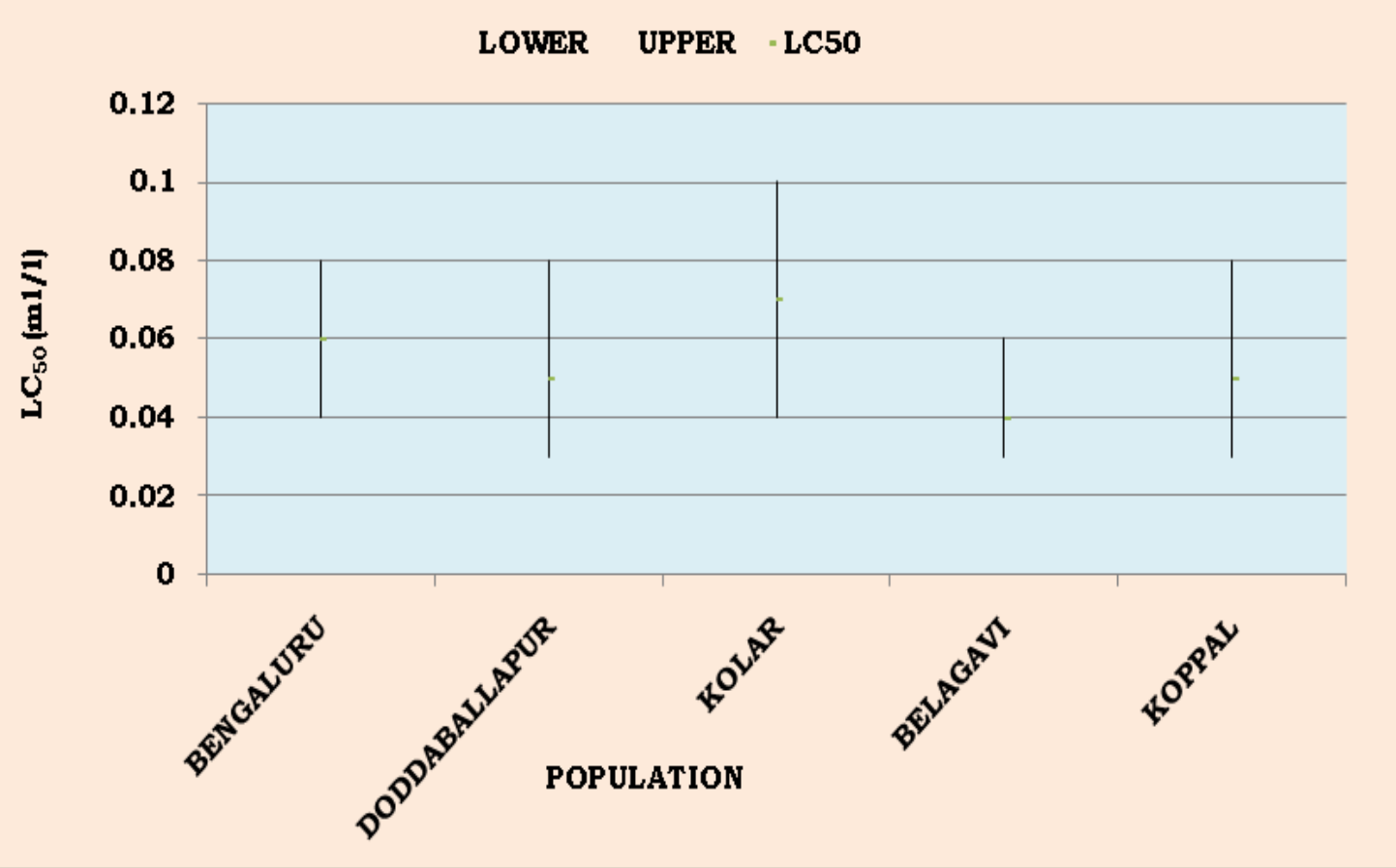


Fig.3 The probit analysis of dosage mortality response of field populations of L. orbonalis to deltamethrin

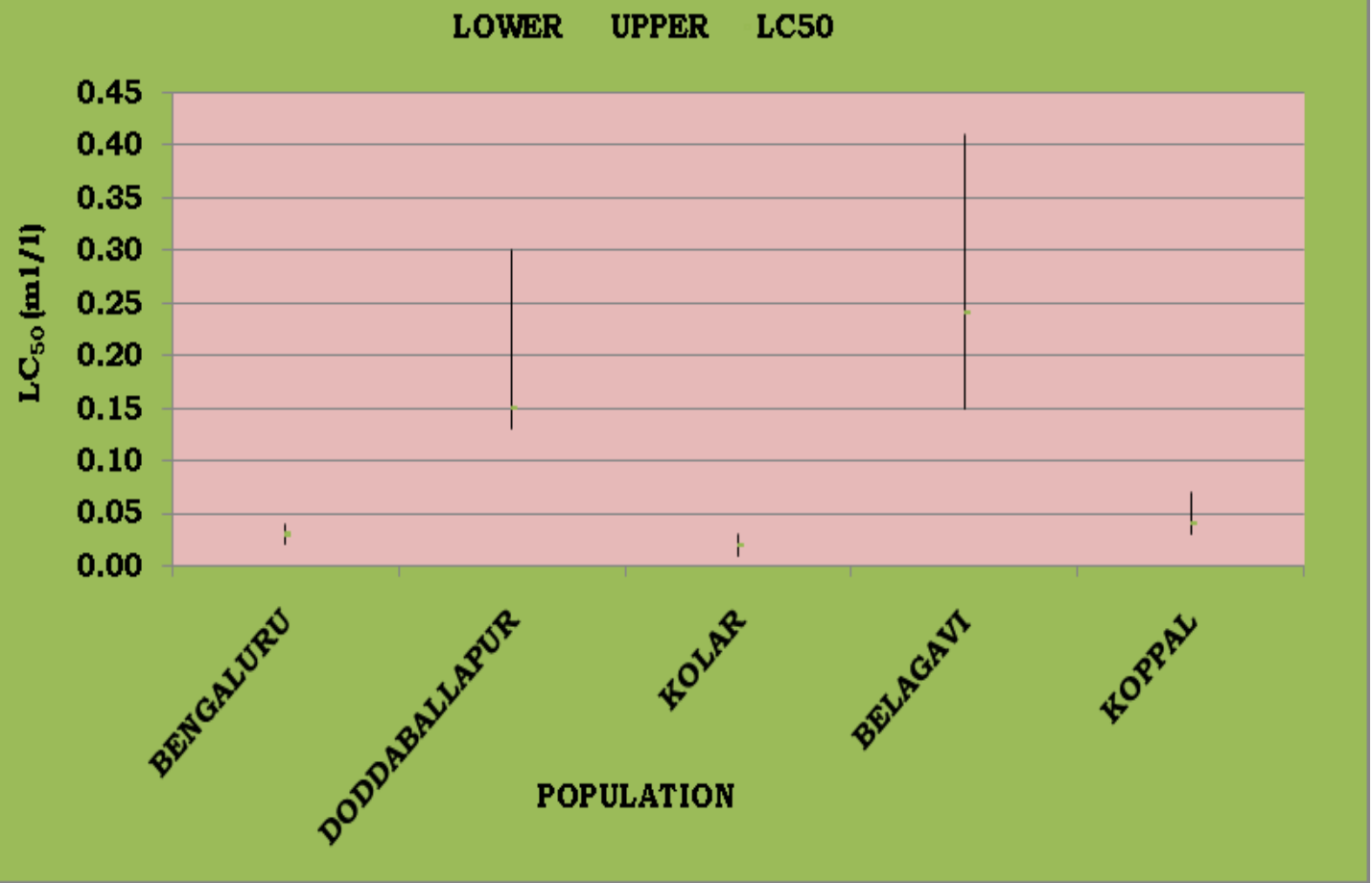

Fig.4 The probit analysis of dosage mortality response of field populations of L. orbonalis to fenvalerate

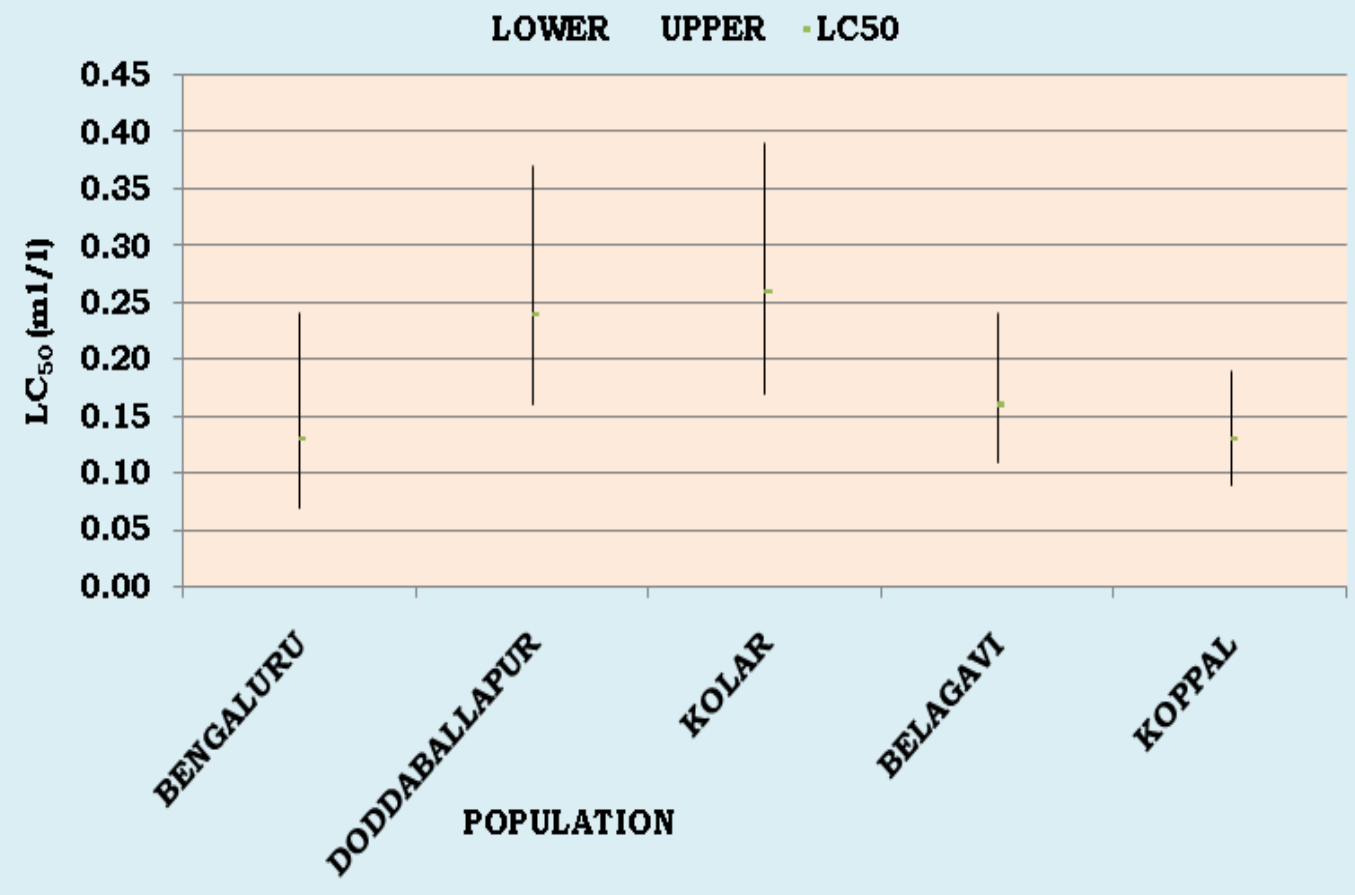


Fig.5 The probit analysis of dosage mortality responses of field populations of L. orbonalis to lambda cyhalothrin

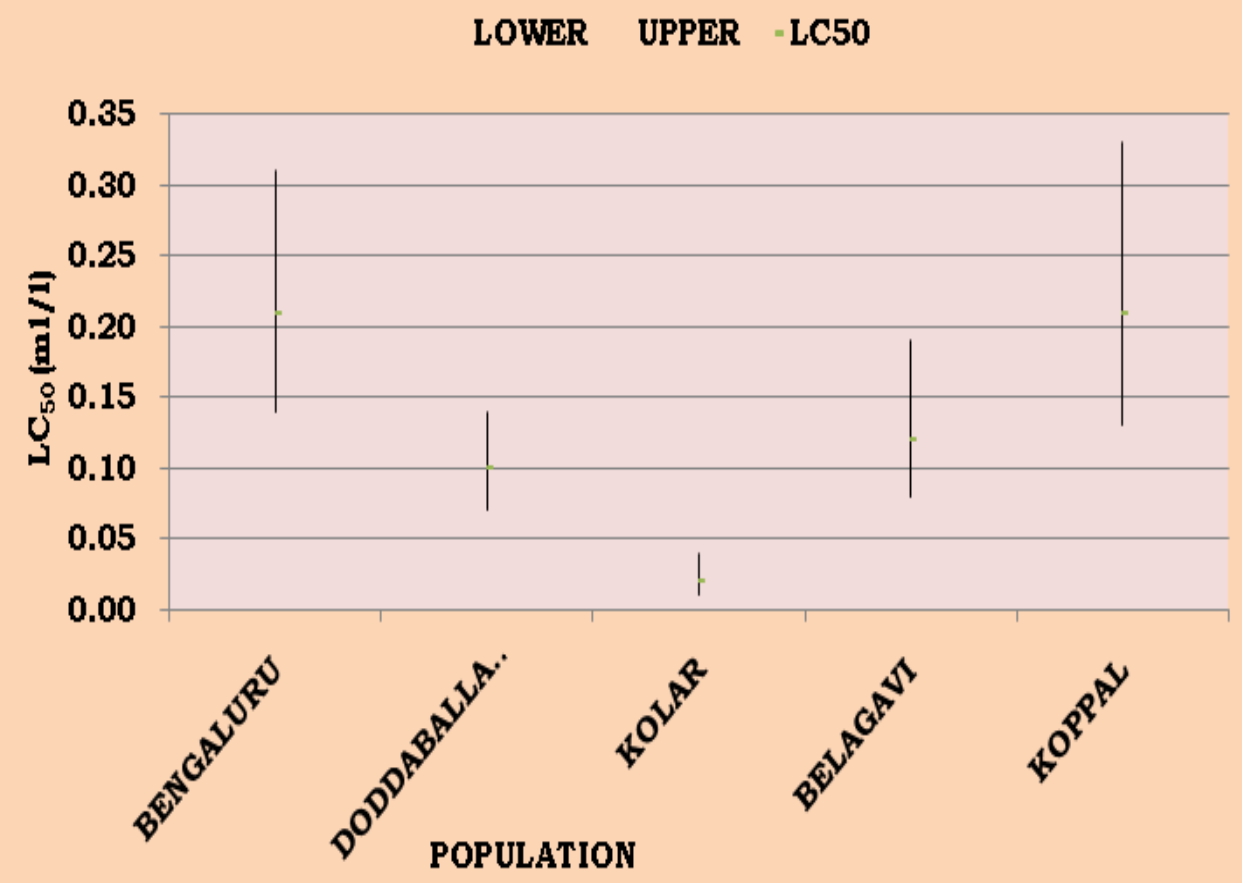

Fig.6 The probit analysis of dosage mortality responses of field populations of L. orbonalis to fenpropathrin

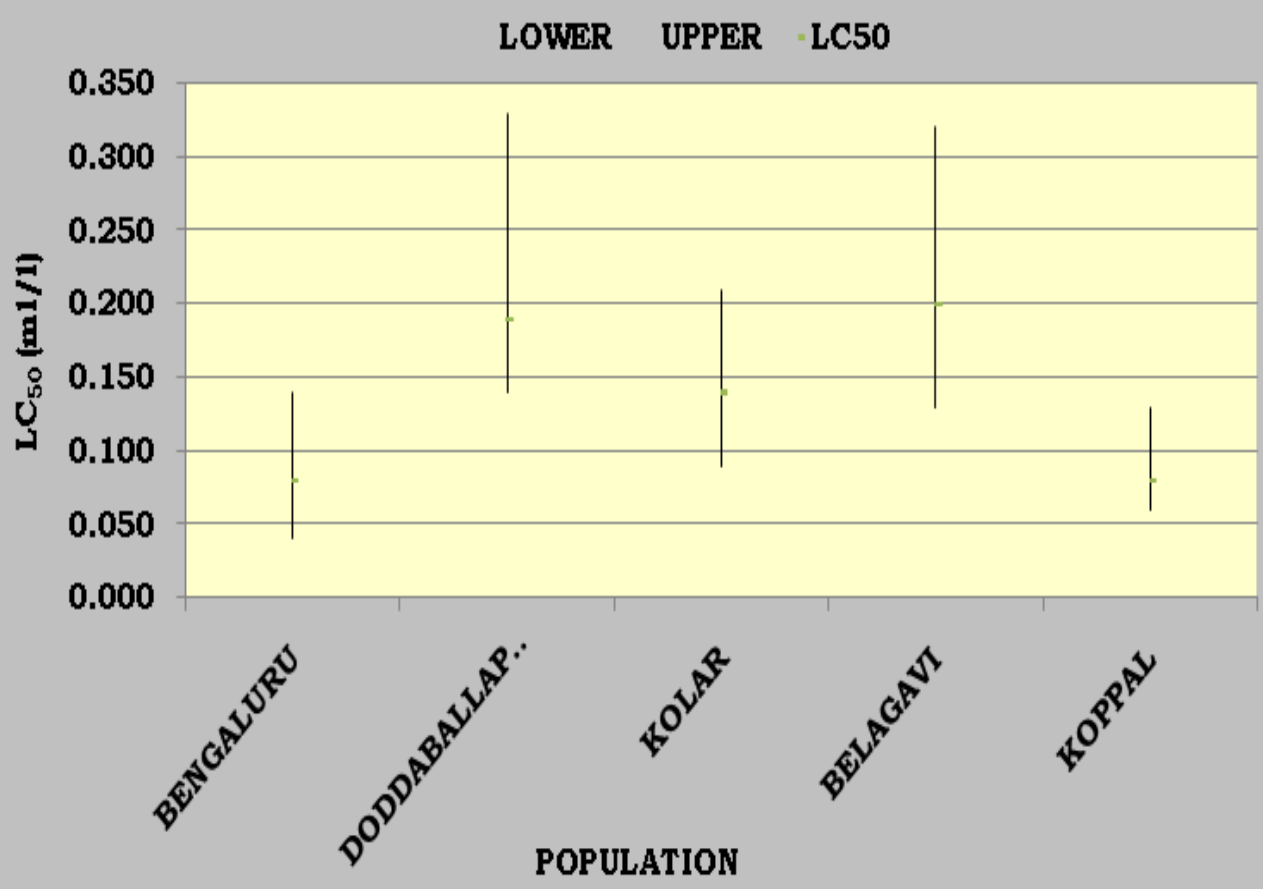


The results of the present work is in agreement with the findings of Ali (1994) who reported that $L$. orbonalis development of resistance to pyrethroid in Bangladesh and observed that in summer season, the farmers of Bangladesh spray almost daily for control of L. orbonalis, whereas in West Bengal, (India) frequency of application exceeds three sprays per week. The presence of such cross or multiple resistances for Jessore (Bangadesh) population was likely since farmers of Jessore area sprayed brinjal fields every day or even twice a day with a variety of insecticides (Kabir et al., 1996). Later on, Rahman and Rahman (2009) reported that 7.28 to 18.19 per cent resistance to three insecticides belonging to carbamate and pyrethroid population was found in Jessore and Gazipur populations of Bangladesh.

From the above research findings were supported by Rahman and Rahman (2009), who reported the variation of mortality estimates for L. orbonalis, the lowest $\mathrm{LC}_{50}$ value was found for Marshal $20 \mathrm{EC}$, Ripcord $10 \mathrm{EC}$ and Basathrin $10 \mathrm{EC}$ for Jessore and Gazipur region and reported mortalities of 73.3, 80.0, 73.3, 73.3 and 73.3 and 80.0 per cent, respectively for Marshal, Ripcord and Basathrin in Jessore and Gazipur districts. The percentage of resistance was higher (18.19 \%) to Marshal 20 EC in Jessore population than in Gazipur (11.52\%). Abrol and Singh (2003) in Jammu evaluated six insecticides and their eight combinations for their efficacy against $L$. orbonalis and reported the combination of endosulfan + deltamethrin and and endosulfan + fenvalerate were highly effective, the other promising treatments were carbaryl + fenvalerate $=$ dichlorvos + fenvalerate $>$ malathion + fenvalerate $>$ fenvalerate + deltamethrin $>$ dichlorvos $=$ carbaryl + deltamethrin $=$ malathion $=$ dichlorvos + deltamethrin $=$ malathion + deltamethrin $>$ endosulfan > carbaryl, respectively. In a study in Punjab, three populations collected from Amritsar, Malerkotla and Hoshiarpur, $\mathrm{LC}_{50}$ values ranged from 0.06 to $1.6 \mathrm{ppm}$ for five different populations with emamectin benzoate showed highest toxicity for Amritsar and Malerkotla populations, while no appreciable differences was observed for Hoshiarpur population for any of insecticides tested (Kaur et al., 2014).

Due to resistance development, it can be assumed that pest management programme may result in reduced levels of control, thereby reduction in crop production. It is therefore, necessary to further take up studies on insecticide resistance management and further monitoring of the resistance levels.

\section{Acknowledgements}

The authors wish to thank the authorities of National Bureau of Agricultural Insect Resources (NBAIR), Bengaluru - 560024, Karnataka, India for their facilities to undertake this work. We acknowledge all technical staff who assisted their help in successful completion of work and also farmers who have cooperated for collection of field samples at different places.

\section{References}

Abrol, D. P., and Singh, J. B. 2003. Relative efficacy of some insecticides against brinjal fruit and shoot borer, Leucinodes orbonalis Guenee, and their impact on fruit yield. J. Asia Pacific Entomol. 6(1): 83-90.

Ali, M. I., 1994. Circumstantial evidence supports insect resistance in Bangladesh. Res. Pest Managt. 6(1), p. 15.

Dover, M. J., and Croft, B. A. 1984. Getting tough: Public policy and the management of insecticide resistance. World resource institute. Study Washington D. C. 
Finney, D. J., 1971. Probit analysis, Cambridge University Press, 3rd Edn, pp. 333.

Isahaque, N. M. D., and Chaudhuri, R. P. 1984. A new alternate host plant of brinjal shoot and fruit borer, Leucinodes orbonalis Guenee in Assam. J. Res. Assam Agric. Univ. 4: 83-85.

Kabir, K. H., Baksha, M. E. Rouf, F. M. A. and Ahmed, A. 1996. Insecticides use pattern on vegetables at farmers' level of Jessore region in Bangladesh. Bangladesh J. Agric. Res. 21(2): 214254.

Kaur, J., Kang, B. K. and Singh, B. 2014. Base line data for insecticide resistance monitoring in brinjal shoot and fruit borer, Leucinodes orbonalis guenee. The Biosci. 9(4): 1395-1398.
Kranthi, K. R., 2005. Insecticide resistance monitoring, mechanisms and management manual. Central Institute for Cotton Research, Nagpur Pp: 80-94.

Rahman, M. M., and Rahman, M. M. 2009. Study on the development of resistance in brinjal shoot and fruit borer against different insecticides. World J. Zool. 4(2): 137-143.

Saxena, J. D., Rai, S., Srivastava, K. M. and Sinha, S. R. 1989. Resistance in the field population of the diamond back moth to some commonly used synthetic pyrethroids. Indian J. Entomol. 51: 265268.

Shelton, A. M., 2010. The long road to commercialization of $B t$ brinjal (eggplant) in India. Crop Prot. 29: 412414.

\section{How to cite this article:}

Murali S., S. K. Jalali, A. N. Shylesha, T. M. Shivalinga Swamy and Gandhi Gracy R. 2017. Documentation of Pyrethroid Resistance against Brinjal Shoot and Fruit Borer, Leucinodes orbonalis Guenee (Pyralidae: Lepidoptera). Int.J.Curr.Microbiol.App.Sci. 6(8): 3260-3270. doi: https://doi.org/10.20546/ijcmas.2017.608.389 